\title{
In the Time of al-Fitạl When Stones Were Still Moist and All Things Spoke: Very Short Arabic Animal Fables and Just-So Stories
}

\author{
Geert Jan van Gelder \\ Laudian Professor of Arabic emeritus, University of Oxford, \\ Oxford, United Kingdom \\ gerard.vangelder@orinst.ox.ac.uk
}

\begin{abstract}
Scholarly attention to speaking animals in Arabic has focused mainly on the larger collections such as Kalïla wa-Dimna, the two sections with animal fables in Alf Layla wa-layla, and the lengthy, brilliant debate in Rasāil Ikhwān al-Ṣafä'. Animal fables such as found in the Pañcatantra, Aesop, and Kalïla wa-Dimna are usually short. There are even shorter fables, however. Arabic literary anthologies contain numerous ultra-short narratives figuring speaking animals, which have been studied less often. This article is concerned with their form and characteristics, and their reception in Arabic literature. Often they are about animal behaviour and characteristics rather than allegories for human behaviour.
\end{abstract}

\section{Keywords}

Arabic literature - fables - speaking animals

Scholarly attention to speaking animals in Arabic has understandably focused mainly on the larger collections such as Kalila wa-Dimna, the two sections with animal fables in Alf Layla wa-layla, ${ }^{1}$ and the lengthy, brilliant debate in Rasāil Ikhwān al-Ṣafä. I shall not discuss them here, nor is there any need to deal with the speaking creatures in the Qurān, where a hoopoe and an

1 Alf Layla wa-layla, I, 288-306 and, in the cycle of King Jalīād and his son Wird Khān, IV, 142-172 (tr. Lyons, The Arabian Nights, I, 613-650, III, 441-502, respectively). 
ant speak and where the expression manțiq al-tayr, the speech of birds, has received ample attention. ${ }^{2}$ Animal fables such as found in the Pañcatantra, Aesop, and Kalïla wa-Dimna are usually short. There are even shorter fables, however. Arabic literary anthologies contain numerous ultra-short narratives figuring speaking animals, which have been studied less often, the main contributions being Brockelmann's article "Fabel und Tiermärchen" published in $1926^{3}$ and Karimi, "Le conte animalier," of $1975 .{ }^{4}$ Franz Rosenthal also discusses some animal fables, mostly Aesopic, found in a manuscript. ${ }^{5}$ Brockelmann and others were particularly interested in the possible origins, whether western or oriental, of the several fables. Brockelmann and Karimi show that not all Arabic animal stories can be traced to non-Arabic sources. In this article I am not primarily interested in origins and sources but rather in the forms, functions, and characteristics of those fables. It will be seen that they vary considerably in form or function and that the short narratives may have shifting shapes and serve different purposes, including philological explanation, fanciful zoological information, moral instruction, literary enjoyment, and humour, usually combined to the point of making it impossible to distinguish clearly between categories. These very short fables lack the at times ponderous style of Aesop and Kalïla wa-Dimna and as a rule they do not explicitly provide a moral. They are often introduced by expressions such as mimmā taqūlu l-Arab 'alä alsinat al-bahǟim, "Among things the Arabs say on the tongues (i.e., put into the mouth) of beasts." Their brevity may reach the level of near-incomprehensibility. In the seminal literary anthology by Ibn Qutayba (d. 276/889), 'Uyūn al-akhbār, one finds: 6

2 See, e.g., Jāhịiz, Hayawān, IV, 8-9, 22, VII, 50-58; Murtaḍā, Amālī, II, 349, 352-353 on the speech of animals (sūrat al-Naml, Q 27:16: manțiq al-țayr; Q 27:18 the speech of the ant; Q 27:22-26: the speech of the hoopoe); see Miller, Man is Not the Only Speaking Animal. Other speaking animals are found in many stories in connection with Solomon/Sulaymān and other prophets. A frog speaks to David/Dāwūd (Damīrī, Hayāt al-hayawān, II, 85-86); a lizard speaks to the Prophet "in fluent, correct, clear, distinct Arabic that was understood by all the people" (ibid., II, 79). People other than prophets also encounter speaking animals. Sufyān al-Thawrī claims to have been addressed by a dog (Abū Nu'aym, Hilyat al-awliy $\bar{a}$, VII, 74; I owe this reference to Christopher Melchert) and wolves spoke to Rāfi b. 'Umayra, Salama b. al-Akwa', and Uhbān b. Aws, nicknamed Mukallim al-Dhi'b (see Damīrī, Hayāt al-hayawān, I, 362; Thacālibī, Thimār al-qulüb, 386-387 and many other sources).

3 Brockelmann, Fabel und Tiermärchen.

4 Karimi, Le conte animalier; the author does not refer to Brockelmann's article.

5 Rosenthal, A Small Collection. For a general survey of animal fables in Arabic, see Irwin, The Arabic Beast Fable. On speaking animals mostly in the larger collections such as Kalila waDimna, al-Namir wa-l-thalab, and al-Asad wa-l-ghawwāș, see Wagner, Sprechende Tiere in der arabischen Prosa.

6 Ibn Qutayba, 'Uyūn al-akhbār, II, 74; cf. Ibn 'Abd Rabbih, 'Iqd, VI, 235. 


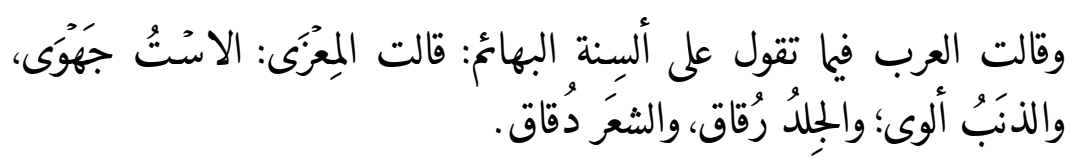

Among the things the Arabs say on the tongues of beasts: The goats said, "The arse bare, the tail curled, the skin thin, ${ }^{7}$ the wool fine."

If this is a fable, then the point of this, apart from offering rhymed prose, is not clear, for why should goats describe themselves in such a pitiful fashion? It is partly solved when one finds longer versions, as in Ibn Durayd's (d. 321/933) dictionary Jamharat al-lugha:

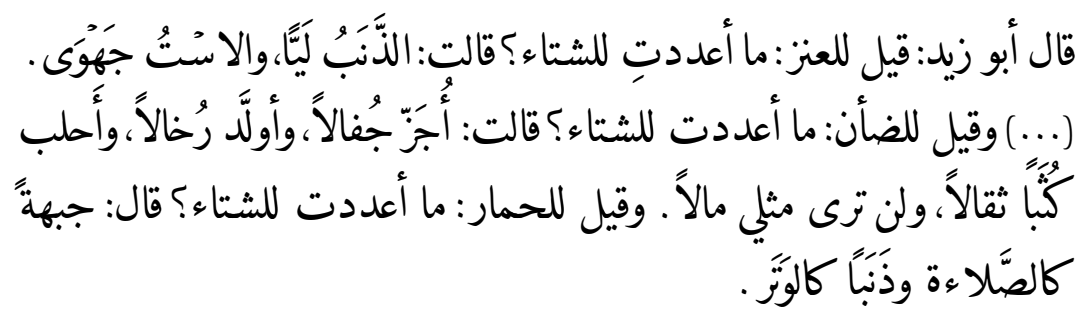

Abū Zayd said: ${ }^{9}$ The goat was asked, "What have you prepared for winter?" She ${ }^{10}$ replied, "The tail is curled, the arse is bare!" The sheep was asked, "What have you prepared for winter?" She replied, "I am shorn of my fleece, I am made to give birth to lambs, I am milked filling heavy pails. You will not see anyone like me in wealth." The donkey was asked, "What have you prepared for winter?" He replied, "A forehead like a stone slab and a tail like a bow-string."

Not all problems are solved, for it is not clear how the donkey will protect himself against winter's harshness with a hard forehead and string-like tail, or if the wealth produced by the sheep will help her; whereas the goat merely seems to complain of having scant protection. The bit about the sheep is also found in Ibn Qutayba, separately and again without the question about winter.11 A yet fuller version is given by al-Suyūṭi (d. 911/1505) in his Muzhir, quoting Ibn

7 Iqd has ziqāq, "(for) water-skins."

8 Ibn Durayd, Jamhara, 1302. The lexicographical glosses have been omitted.

9 Presumably Abū Zayd al-Anșārī (d. ca. 215/83o), but the text is not found in his Nawādir; Zabīdī, Tāj $(J H W)$ quotes it saying it is from Abū Zayd's Kitāb al-Ghanam.

10 I have used "she" and "he" rather than "it" in my translations referring to speaking animals.

11 Ibn Qutayba, 'Uyūn al-akhbār, II, 78. 
Durayd and adding a quotation from the Amāli of Tha'lab (d. 291/904), ${ }^{12}$ which to the above-mentioned animals adds a dog, who says that his preparation for winter consists in wagging his tail and lying down at the door of his master. The shape-shifting nature illustrated by this tale is compounded by yet another version involving a human instead of animals, a version that may be older than the animal one. Al-Jāhiz (d. 255/868-9) quotes the following:13

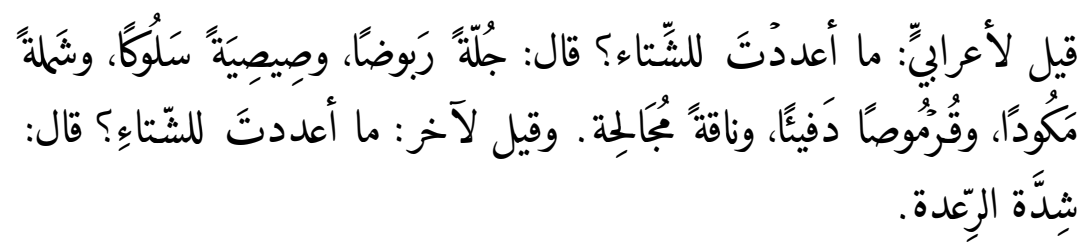

A Bedouin was asked, "What have you prepared for winter?" He replied, "A large basket for dates, a scoop that is easy to handle, a cloak that will last, a warm hole in the ground, and a milk-yielding she-camel." Another was asked, "What have you prepared for winter?" He replied, "Intense shivering."

So what is the moral of this fable in its several versions? The answer is that it is no true fable at all, or at least not a fable in the traditional sense of a short animal tale that offers a lesson or moral. I have omitted the lexicographical explanations that accompany the texts in many of the sources, but these explanations provide a clue: they are part of lexicography, examples of old Arabic eloquent diction, with gharib and $s a^{c}$, and they provide information about the traditional nomadic or semi-nomadic life of the Bedouin Arabs. Brockelmann briefly mentions this kind of sayings in his "Fabel und Tiermärchen,"14 justifiably, because the texts about the sheep and the goat are more than mere lexicography and eloquence, for they are also aetiological texts, or, to use Kipling's term, just-so stories. A version from al-Azmina wa-l-amkina by al-Marzūqī (d. 421/103o) makes this clearer:15

12 Suyūțī, Muzhir, II, 546-547. Tha'lab's Amālì are his Majālis, but the text has not been found there. The oldest source is Așma'ī, $a l-S h \bar{a}^{\prime}, 54$.

13 Jāhị, Bayān, III, 230-221; cf. Marzūqī, Azmina, 267.

14 Brockelmann, Fabel und Tiermärchen, 119-120, on versions of this story.

15 Marzūqīi, Azmina, 270. 


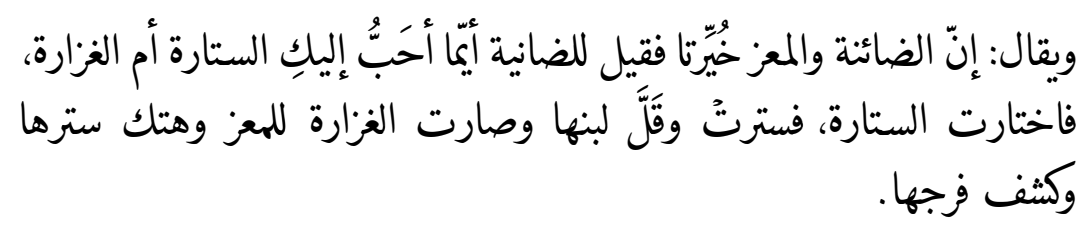

It is said that the ewe $\left(\underline{d} \bar{a}^{3} i n a\right)^{16}$ and the goat $\left(m a^{c} z\right)$ were given a choice. The ewe was asked, "Which would you rather have, cover (sitāra) or plenty (ghazāra)?" She chose cover. Thus she was covered but her milk was scant. The goat got plenty but "her cover was rent" (hutika sitruhā, meaning "she was disgraced") and her genitals bared.

The ewe's "cover" is not only her thick fleece but especially the fatty tail that covers her backside; the goat shamefully lacks such a cover.

There are several such aetiological tales that give fanciful explanations of the appearance and other characteristics of animals. A well-known one is the story of how the frog lost his tail. ${ }^{17}$ Here is the version offered by al-Jāhiz in his al-Hayawān: ${ }^{18}$
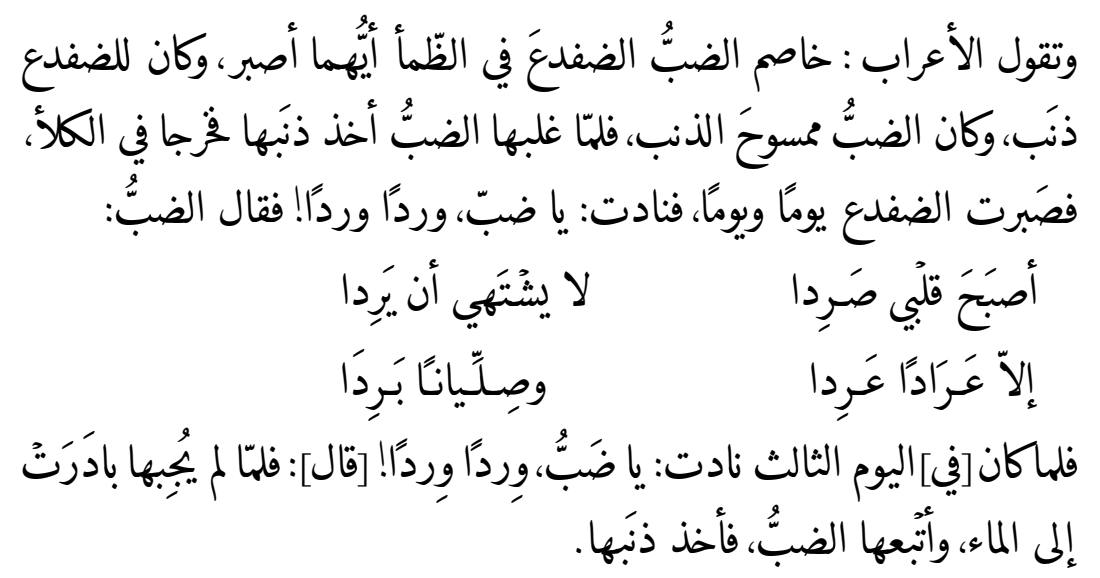

\footnotetext{
16 The edition wrongly has dāniya.

17 Brockelmann, Fabel und Tiermärchen, 118; Karimi, Le conte animalier, 51; Jāḥiz, Hayawān, V, 528 (summary), VI, 125-128; Ibn Qutayba, Ma'ānī, 641; Maydānī, Majma' al-amthāl, I, 400 (at the proverb arsah min difdac, "having a scrawny behind like a frog," as in Zamakhsharī, Mustaqșā, I, 139-140); Tha ālibī, Thimār al-qulūb, 634; Ma'arrī, Șāhil, 181. For a version with a fish instead of a frog, see Damīī, Hayāt al-hayawān, II, 78. The first two rajaz lines, but not the fable, are found already in Khalìl, al-'Ayn $\left(J Z^{\prime}, S \subseteq R D\right)$.

Jāhị, Hayawān, vi, 125-126.
} 
The Bedouins say that the lizard (dabb) and the frog (difdi) disputed about which of them could endure thirst better than the other. The frog had a tail and the lizard had only a stunted tail, but when the lizard had won he took the frog's tail. They had gone out to feed. The frog endured thirst for a day and another day. Then he cried out, "Lizard, to the water, to the water!" The lizard said, ${ }^{19}$
My heart will not let me,
It does not want to drink
But only to take hard ' $\operatorname{ara} d^{20}$
And cold șilliyān. ${ }^{21}$

On the third day the frog cried out, "Lizard, to the water, to the water!" Receiving no reply, she ${ }^{22}$ hurried to the water. The lizard followed her and took her tail.

Al-Jāhiz continues with a poem of thirteen lines about rain by Ibn Harma (d. 176/792), which contains the following lines: ${ }^{23}$
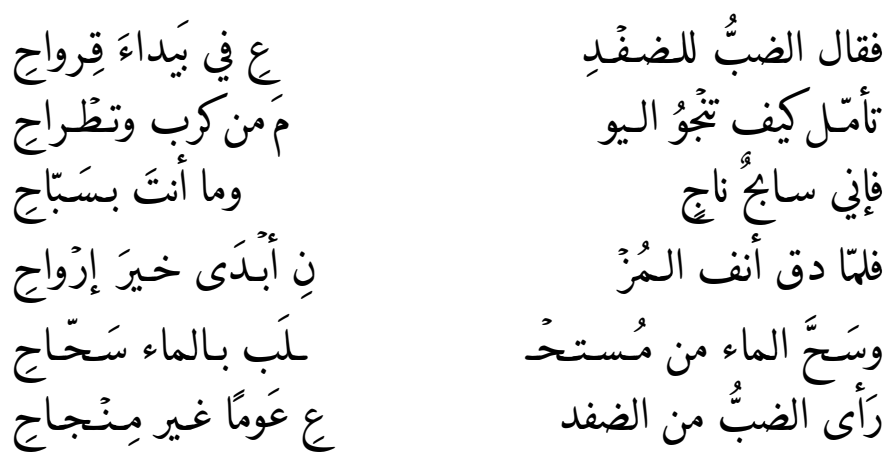

The lizard said to the frog

in the empty desert,

\footnotetext{
19 Verses in rajaz metre.

20 Said to be a plant, hard, eaten by camels, growing in places remote from water (see Lane, Lexicon).

21 Said to be a plant with a thick stem, eaten by camels and donkeys (see Lane, Lexicon).

22 In al-Jāhiz's version the frog is female/feminine, even though the form used is the masculine difdi', not difdi'a.

23 Jāhiz, Hayawān, vi, 127; Ibn Qutayba, Ma'ānī, 641 (the first three verses); Ibn Harma, Shi'r, 95-96. On this poem see Salhi and Alqarni, New Images in Old Frames, 78-79.
} 
"Think how you can be saved today from distress and mishap!

For I shall swim and save myself but you cannot swim!"

When the nose of the clouds was crushed (like perfume) it made the water smell good (?), ${ }^{24}$

And the rain poured down from the udders of a cloud,

The lizard saw that the frog was not a successful swimmer.

The connection between these lines and the prose story is tenuous. There is no mention of tails and one would think that frogs are by no means inferior to lizards in swimming; perhaps the poem has only a part of the story. Al-Jāhiz then quotes a verse by the mukhadram poet al-Kumayt b. Tha'laba that is more to the point: ${ }^{25}$
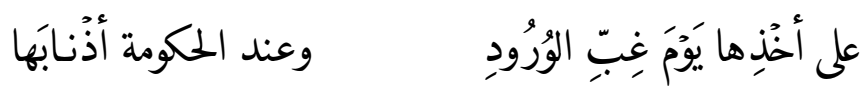

When they took, the day after coming to the water, at the arbitration, their tails.

Akin to the just-so stories are texts about the onomatopoeic names of birds. In his book on proverbs al-Maydānī (d. 518/1124) writes: ${ }^{26}$

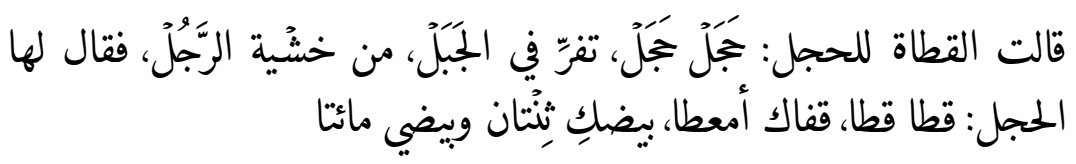

24 Interpretation of the verse unclear. The editor of Ibn Harma's poetry explains the second hemistich as "(the lizard) smelled a human being," but this does not explain the word khayr, and the presence of humans is unexpected. My interpretation is based on the fact that the dictionaries connect arwaha with smelling and water, which seems supported here by the mention of "nose." Salhi and Alqarni translate it as "the frog showed that it could escape best," which may be correct but seems to contradict what follows about the ineffectiveness of the frog's swimming.

25 Jāhịiz, Hayawān, vi, 128; Maydān̄̄, Majma al-amthāl, I, 400; Zamakhsharī, Mustaqșāa, I, 140. Unfortunately, no more lines of the poem are known.

26 Maydānī, Majma'al-amthāl, II, 215, Ibn Manzūur, Lisān al-Arab (HJL); a different version in Tha'ālibī, Thimār al-qulūb, 644. 
The sandgrouse ( $q a t \underline{a})$ said to the partridge (hajal), "Partridge, partridge (hajal, hajal), you flee to the mountains (tafirru fi l-jabal), out of fear for man (min khashyati l-rajul)!"27 The partridge replied, "Sandgrouse, sandgrouse ( $q a t \underline{a}, q a t \bar{a})$, your neck is hairless (am'ața), your eggs are (only) two and my eggs are two hund!" 28

In this story the birds pronounce each other's names. Rather better known and more logical is the saying that the sandgrouse, $q a t+\bar{a}$, pronounces his own name; poets called it șādiqa, "speaking the truth." ${ }^{29}$ These poets, explains al-Jāhiz, present the bird as giving truthful information, "even though the sandgrouse does not intend this." The Arabs, he continues, take anything they can hear and understand as clear speech (bayān), as when Dhū l-Rumma says that sheep call for water $(m \bar{a})$. The $z \bar{a} g h$ (rook, or crow, or jackdaw, or chough?) also cries out his name, $z \bar{a} g h z \bar{a} g h !$, after reciting a poem in eloquent Arabic, bi-lisān fașịt țaliq dhaliq, in a story. ${ }^{30}$

The just-so stories are different from the moralistic tales such as those in Kalilla wa-Dimna. The typical Aesopic fable or Kalïla wa-Dimna tale uses speaking animals to speak about the human world and teach a moral lesson. A lion or a fox may be chosen because the former is strong and the latter is clever, but the fables do not explain the lion's strength and the fox's cunning, which are taken for granted as being obvious. The aetiological tales, however, are specifically about the speaking animals themselves, not about the human world. ${ }^{31}$

Some tales contain neither aetiology nor morality but merely describe events in the animal world, at the same time offering glimpses of Bedouin life. A lizard speaks again in a story quoted (twice) by al-Jāhịiz: ${ }^{32}$

27 Or "fearfully, cowardly," reading min khashyati l-wajal as in Lisān al-'Arab.

28 Miatā, instead of the correct miatān, "two hundred," for the sake of the metre and (poor) rhyme.

29 Jāhị, Hayawān, v, 287 quotes verses by al-Kumayt and al-Farazdaq; cf. ibid. v, 578-579. See also Tha'ālibī, Thimār al-qulūb, 482; Maydānī, Majma' al-amthāl, I, 515-516 (aṣdaq min qațāh, "more truthful than a sandgrouse"); Damīrī, Hayāt al-hayawān, II, 253, 255 and many other sources.

30 Jarīīi, Jalīs, II, 71-72; Sarrāj, Mașāri' al-'ushshāq, I, 85-86; Damīīi, Hayāt al-ḥayawān, II, 2. Among onomatopoeic bird names is surely the 'aq'aq (magpie), as al-Damīrī says (II, 148), who remarks that al-Jāhiz thought otherwise and connected the name with the verb 'aqqa ("being a bad parent"). But al-Damīrī misrepresents al-Jāhiz, who does not posit an etymological connection (see Hayawān, III, 180, v, 151, VI, 478).

31 There are aetiological tales in which animals do not speak; for some examples see Karimi, Le conte animalier.

32 Jāhịi, Hayawān, IV, 165 and VI, 132-133; he quotes al-Aṣma'î. 


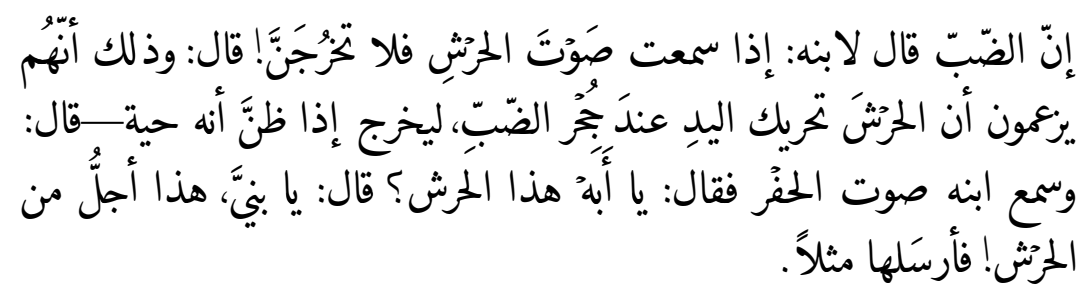

A lizard said to his son, "If you hear the sound of scratching (or tapping, harsh) you must not go outside!" Harsh, they say, is moving the hand near the burrow of a lizard, so that it would come out, thinking it is a snake. The son heard the sound of digging and said, "Daddy, is this scratching?" "Son," the father replied, "This is worse than scratching!" This became a proverb.

And, indeed, the saying is found in collections of proverbs. ${ }^{33}$ Three anonymous rajaz lines quoted in Sībawayh's Kitāb are said to have been spoken by yet another lizard (this paper seems to be teeming with lizards) whose burrow has been targeted, probably by Bedouins, who are often described as being fond of lizards: ${ }^{34}$

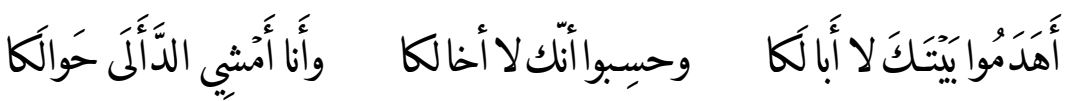

Have they destroyed your house? Woe!

And did they think you had no brother?

And I scurrying around you!

The story behind these lines, if ever there was one, is lost. Al-Mubarrad (d. 285/898), in a chapter on "Lies of the Bedouins" (takädhïb al-a'rāb), relates

33 Mufaḍḍal, Fākhir, 235-236; Abū 'Ubayd al-Bakrī, Faṣl al-maqāl, 471; 'Askarī, Jamhara, I, 66, 269; Maydānī, Majma 'al-amthāl, I, 244-45; Zamakhsharī, Mustaqșā, II, 50-51, 384; see also Ibn Qutayba, Macānī, 643; Ibn Durayd, Jamhara, 512, 1141; Murtaḍā, Amā̄l̄̄, I, 235; Ibn Manzūu, Lisān al-Arab (HRSh); Baghdādī, Khizāna, XI, 462. See also Brockelmann, Fabel und Tiermärchen, 121.

34 Sỉbawayh, Kitāab, I, 176, see also Jāhịiz, Hayawān, vI, 128 (where the lines are attributed to Abū Ziyād, i.e., Abū Ziyād Yazīd b. 'Abdallāh al-Kilābī); Ibn Qutayba, Ma'ān̄ī, 65o, and many other sources. Abū Ziyād al-Kilābī, a Bedouin who settled in Baghdad, author of a Kitāb al-nawādir (2nd half of 2nd/8th century, see Sezgin, Geschichte, II , 86, Ibn al-Nadīm, Fihrist, I, 121), also composed a strange poem with multiple rhymes, or rather a series of short poems, containing a dialogue between a Bedouin and a hyena, quoted in Jāḥiz, Hayawān, VI, 443-445 (summarised in Karimi, Le conte animalier, 53-54). 
that Abū 'Umar al-Jarmī asked Abū 'Ubayda (d. 210/825) about who composed them. He replied, "The Bedouins say that the lizard said them to his young (hisl) in the days when things still spoke (ayyām kānat al-ashyä tatakallam)." ${ }^{35}$ Al-Thaālibì (d. 429/1038) discusses this interesting mythical epoch in his Thimār al-qulüb, in the entry of zaman al-fitahl, "the time of al-fitahl."36 The passage is worth looking at in some detail.

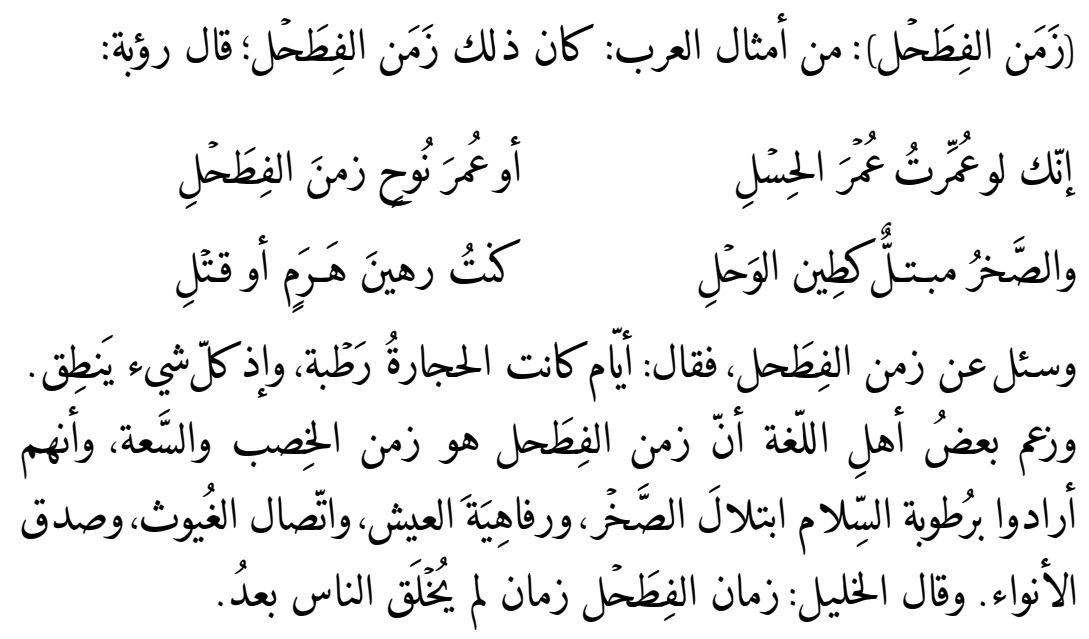

"The time of al-fitahl" is one of the sayings (amthāl) of the Arabs, who say, "That was in the time of al-fitahl." Ru'ba [b. al-'Ajjāj, d. 145/762] said, ${ }^{37}$

Though I ${ }^{38}$ may live as long as a young lizard

Or as long as Noah in the time of al-fitahl,

When rocks were still wet like the clay of mud,

I will (in the end) be a victim of decrepitude or be killed.

35 Mubarrad, Kāmil, II, 215; similarly, Ibn Hạdūn, Tadhkira, vi I, 340-341 (min akādhïbihim), Suyūțī, Muzhir, II, 5 O4.

36 Tha'ālibī, Thimār al-qulūb, 642-644. He quotes passages from Jāḥiz, Hayawān, v, 202-206 on the motif of the rocks and the prickly plants being soft.

37 See Ru'ba, Dīwān, 128; Jāhịiz, Hayawān, IV, 202; Ibn Qutayba, Ma'ānī, 648; Mubarrad, Kāmil, II, 217; Qālī, Amālī, I, 234; 'Askarī, Jamhara, I, 254; Maydān̄̄, Majma' al-amthāl, II, 59, 176; Zamakhsharī, Mustaqșā, II, 213; Marzūqī, Amkina, 170; Damīrī, Hayāt al-ḥayawān, I, 234, and many other sources, including dictionaries such as Zabīdī, Tāj al-'arūs (FṬ̂L). The Dīwān has fa-qultu law 'ummirtu, "So I said, were I to live ..."

$3^{8}$ Tha'ālibī, Thimār al-qulūb and some other sources have 'ummirta and, in the fourth line, kunta, but the context in the poem requires the first person, as in the Diwwann. 
$\mathrm{He}^{39}$ was asked about the expression "the time of al-fitahl." He explained: "The days when the stones were still wet, when all things could speak." Some lexicographers say that "the time of al-fitahl" was a time of fertility and plenty. ${ }^{40}$ With the "wetness of stones" they meant that the rocks were moist, that life was opulent, rain fell steadily, and the rain-stars were reliable. Al-Khalī ${ }^{41}$ says, "The time of al-fitahl is the time when people had not yet been created." 42

It is likely that Ru'ba did not know the exact meaning of al-fitahl and it is clear that the Arab lexicographers did not have a clue about the meaning and origin of the word, which is in fact an Arabicised form of Ptahil, the name of the Mandaean demiurge who created the earth from muddy clay. ${ }^{43}$ To Ru'ba the word merely represented "a soggy primordial time," as Kevin van Bladel aptly put it. Al-Tha'ālibī continues:



39 Although the context suggests that this is Ru'ba, Van Bladel has found in an unpublished commentary on Ru'ba's poetry by Muhammad b. Habīb that it was in fact al-Aṣmāî (From Sasanian Mandaeans to Șābians, 16 note 37; for another translation of the lines by Ru'ba see $15^{-16) .}$

40 Ibn Manzūr, Lisān al-Arab (FṬHL): ataytuka 'ām al-fițahl wa-l-hadmala, ya'nī zaman al-khișb wa-l-rîf.

41 Khalīl, al-'Ayn, III, 334 (entry FṬṭL). See also Van Bladel, From Sasanian Mandaeans to Șābians, 15-17.

42 According to a story told in ps.-Ibn Iyās, Badā’i $i^{`}$ al-zuhūr (possibly by al-Suyūṭī), 44, animals stopped speaking soon after the creation of man. "When Adam was ploughing the earth with two oxen one of them stopped and Adam beat it with a stick he held in his hand. Then God the Exalted made that ox speak. It said, 'Why do you beat me?' 'Because you did not obey me!' The ox replied, 'God was kind to you since He did not beat you when you disobeyed Him!' Adam cried and said, 'O God, everything scolds me, even animals!' Then God commanded Jabrā̄il/Gabriel to wipe (yamsaḥ 'alā) the tongues of animals, striking them dumb. They had been speaking before Adam's descent."

43 See Van Bladel, From Sasanian Mandaeans, 2, 16; Kraeling, The Mandaic God Ptahil, 156-157, on the lines by Ru'ba, with Ahlwardt's German translation. The first to connect al-Fițaḥl with the Mandaean (or “Ṣābian”) Ptahil was De Goeje. 

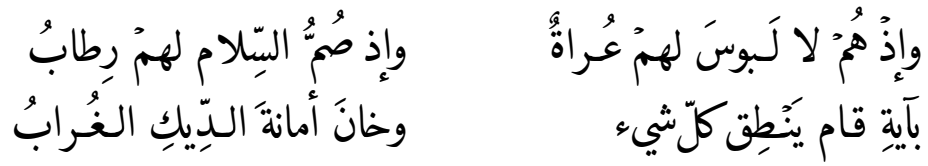

Al-Qāḍī Abū l-Ḥasan 'Alī b. 'Abd al-'Azīz"44 says: That they speak of the days the stones were still wet and that everything could speak, that is what is current among ignorant nations. It is also evident among gullible Arabs and the common people. Ibn [sic] Umayya b. Abī l-Ṣalt, one of the sages of the Arabs and who specialised in transmitting (such ideas), says, ${ }^{45}$

When they did not wear clothes and were naked and when the solid rocks were still wet,

As in the divine sign:46 "Then all things stood up speaking." and the crow betrayed the trust of the cock.

This verse refers to the just-so story about how the cock lost the use of his wings and became a prisoner forced to cry out at dawn, which is told in another poem by Umayya and mentioned in al-Jāhiziẓ's al-Hayawān and later sources. ${ }^{47}$ The cock and the crow were drinking together. When it was time to pay the crow offered to get money and went off, leaving the cock with the taverner as surety, but he betrayed him and did not return.

Al-Tha'âlibì goes on to say that the idea of the rocks being soft and then hardening was not intended as a kind of scientific explanation but the result of fancifully imagining a primeval epoch in which animals could speak as rational beings and when the branches of the sa'dān (a prickly plant) and the twigs of the sayāl (wild artichoke?) were still soft and green. ${ }^{48}$ It is possible, he says,

44 He is also known as al-Qāḍi al-Jurjānī (d. 392/10o1), author of al-Wasāta, on the poet al-Mutanabbī. The quotation is not from this book and has not been found elsewhere.

45 Umayya b. Abī l-Ṣalt, Dīwān, 23-24; Khalīl, al-'Ayn, III, 334 (line ib only); Jāḥiz, Hayawān, IV, 196-197; Ibn Qutayba, Shi'r, 459; idem, Ta'wīl mukhtalif al-Hadīth, 410; Maqdisī, al-Bad' wa-l-ta'rīkh, III, 25; 'Askarī, Awā̉il, 43; Ma'arrī, al-Ṣāhil wa-l-shāhịj, 249; Jawālīqī, Sharh Adab al-kātib, 202; Baghdādī, Khizāna, I, 249.

46 Maqdisī, al-Bad' wa-l-ta'rīkh: bi-annahu qäma. For bi-āyati with the following genitive taken by a sentence, compare the examples in Baghdādī, Khizāna, VI, 512-519. I have translated àya as "divine sign" because it does not strictly refer to a Qur'ānic verse here, even though there is an obvious connection to Q Fușșilat 41:21: anțaqanā llāhu lladhi anțaqa kulla shay'in.

47 Umayya Ibn Abī l-Ṣalt, Dīwān, 153; Jāḥiz, Hayawān, II, 319-321, 325-326; Abū l-Ṭayyib al-Lughawī, Marātib, 88-89; Nuwayrī, Nihāyat al-arab, X, 222-23; Brockelmann, Fabel und Tiermärchen, 118-119.

48 See Jāhịiz, Hayawān, IV, 205. 
that by this those who invented the stories intended to instil wisdom in people, wanting to make them familiar with understanding things, by inventing parables (amthāl) mixed with some jesting ( $h a z l)$, incorporating seriousness in the fun (mazh), so that people would be more receptive. People with undiscerning minds would therefore believe that animals could speak and express themselves. They invented additional stories. The Arabs were particularly adept, more than all other nations, because they are so fond of speech and gifted with the ability to be versatile in their speech. They composed poetry and rhymed prose, such as what is told about the lizard and his ability to endure being without water better than any other living being. ${ }^{49}$ Thus far al-Tha'ālibì.

Animal fables receive very little attention in traditional Arabic literary criticism, which had little interest in narrative, especially when unadorned, anonymous, and in prose. There is no $s a j$, badi , or poetry in Kalīla wa-Dimna. Muhammad b. 'Abd al-Ghafūr al-Kalā'ì, a sixth/twelfth-century Andalusian literary critic, is exceptional in having a chapter in his I hkām șan'at al-kalām devoted to maqāmāt and hikāyāt. ${ }^{50}$ After quoting four maqāmas by Badī al-Zamān al-Hamadhānī he turns briefly to fables:51

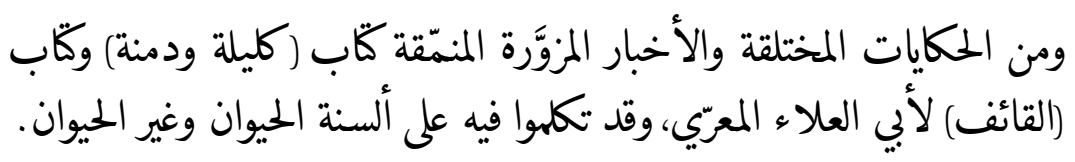

Among the invented tales and fictional, embellished reports ( $\min$ al-hikāyāt al-mukhtalaqa wa-l-akhbār al-muzawwara al-munammaqa) are Kalīla wa-Dimna and al-Qä̉if by Abū l-Alā' al-Ma'arrī, in which they speak quoting animals and non-animals.

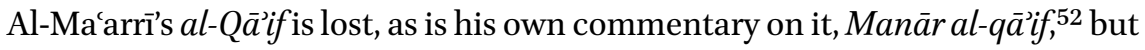
al-Kalāī quotes four brief stories, three of which are about animals that speak. Abū l-Alā's fables are admirably short, as fables should be. He uses saj'sparingly and it does not detract from the quick flow of the narrative. Al-Kalāci says that he prefers Abū l-Alā"s fables to Kalïla wa-Dimna ${ }^{53}$ because they are beautifully written, with ihsān and ibdā', wa-huwa aktharu min Kalīlata waDimnata waraqā, wa-afsaḥu talaqā, wa-atyabu shamiman wa-'abaqā, which I

49 See above, "How the frog lost his tail."

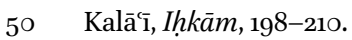

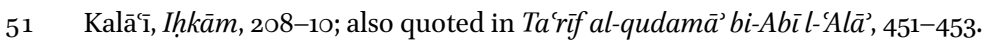

$5^{2}$ Yāqūt, Mújam al-udabā', III, 16o; Șafadī, Wāfì, viI, 103; Ḥājjī Khalīfa, Kashf, II, col. 1827.

53 Kalāì I Inkām, 210. 
find difficult to translate but which seems to say that al-Kalāī thinks that the fables of al-Ma'arrī are more lush, run faster, and have more flavour (literally, "fragrance") than Kalīla wa-Dimna. Perhaps al-Kalāī likes the rhymes and the artifice, or possibly also the unveiled sarcasm evident in this and other fables, with their ambiguities. Since these fables are relatively unknown I quote one of them here: 54

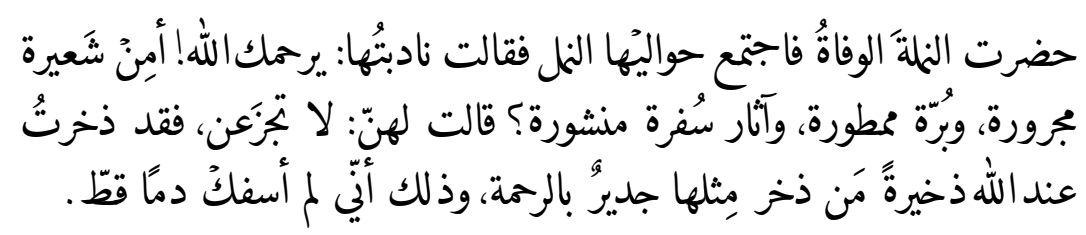

An ant (namla) was dying. The other ants gathered around him. A female mourning ant said, "God have mercy on you! Is there a grain of barley dragged (majrüra), a grain of wheat on which the rain has fallen (mamțüra), or the remains of a tablecloth that was spread (manshüra)?" The ant replied, "Do not worry, for I have amassed with God a store that entitles the one who stored it to mercy: I have never shed blood."

We may wonder if al-Ma'arrī was wholly serious about this dying ant: why should it be rewarded for not having done what it could not have done, and since when can ants enter Heaven? In the second fable a small bird whose chicks had been the victim of a snake year after year nevertheless refrains from gloating when the snake has turned blind; it reads as a counter to the tale of the crow and the snake (al-ghurāb wa-l-aswad) in Kalila and Dimna, in which the crow, helped by a cunning jackal, has his revenge on the snake who has eaten its chicks. ${ }^{55}$ In the third fable there is a blind lion who becomes a herbivore, which would sound ridiculous coming from most writers; Abū l-Alā', a confirmed vegan from conviction, rather than forced by his blindness, might actually have been semi-serious about such an animal. These are no just-so stories but moral tales of a vegan and pacifist. He was fond of letting animals speak, as is obvious from other works of his, notably al-Ṣăhil wa-l-shāhij but also Risälat al-ghufrān, where a lion, a wolf, an oryx, an onager, and several snakes speak. It is somewhat disappointing, therefore, that he, like others, dismissed the fable of the frog and the lizard as "lies (akādhīb), produced by

54 Kalācīi, I $h k \bar{a} m, 209$.

55 Ibn al-Muqaffac', Kalïla wa-Dimna (Beirut, 1922), 81-84, (Beirut, 1984), 94-96. 
people of Scriptures, the Jews and the Christians, heard by Umayya b. Abī l-Șalt and others, who versified them." ${ }^{56}$ And he says this, incongruously, in his Epistle of the Neigher and the Brayer, a book full of speaking animals. However, with al-Macarri there is always a chance that his tongue is in his cheek.

The very short, anonymous tales with speaking animals are found scattered in many sources, such as the dictionary of animals by al-Damīrī (d. 808/1405), Hayāt al-hayawān al-kubrā, and the several books on proverbs such as Jamharat al-amthāl by Abū Hilāl al-'Askarī (d. ca. 404/1010) and al-Maydānīs Majma' al-amthāl. Clusters of them are also contained in several thematically arranged anthologies, notably Nathr al-durr, the large anthology of prose by al-Ābī (d. 421/103o), ${ }^{57}$ Muḥậ̣arāt al-udabā' by al-Rāghib al-Iṣfahānī (d. early 5th/11th century), ${ }^{58}$ and in Ibn al-Jawzì's (d. 597/1201) al-Adhkiy $\bar{a}$, a book about clever people, or rather clever creatures, because the last two chapters are about clever animals. ${ }^{59}$ Other clumps of tales are offered by Ibn Abī 'Awn (d. 322/934) in his al-Ajwiba al-muskita, ${ }^{60}$ al-Hușrīs (d. 413/1022) Jam' al-jawāhir, ${ }^{61}$ Ibn Ḥamdūn's(d. 562/1166)anthologyal-Tadhkiraal-Hamdüniyya ${ }^{62}$ and al-Marzūqī's al-Amkina wa-l-azmina. ${ }^{63}$

Such clusters usually offer a mélange of Aesopic and other Greek fables ${ }^{64}$ and "indigenous" Arabic tales. Among the sixteen fables with speaking animals offered by al-Ābī, for instance, one finds familiar Aesopic tales, such as the one about the lion, the wolf, and the fox, in which the fox says he has learned a lesson from the severed wolf's head; ${ }^{65}$ the fable known as "Sour Grapes" involving

56 Ma'arrī, al-Șāhil wa-l-shāhịj, 249.

57 Ābī, Nathr al-durr, VII, 275-279: Amthāl wa-nawādir 'alā lisān al-bahā'im.

58 Rāghib al-Iṣbahānī, Muḥạdarāt, II, 415-417: Hikāyāt 'an al-bahä̉im.

59 Ibn al-Jawzì, Adhkiyā', 298-308, Ch. 32: Fì mä dhukira 'an al-hayawān al-bahīm mimmā yushbihu kalām al-ädamiyyīn; 309-314, Ch. 33: Fì dhikr mā ḍarabat'hu l-Arab al-hukamā' mathalan 'alā alsinat al-hayawān al-bahīm mimmā yadullu 'alā l-dhakā'. Ibn al-Jawzì's alMud'hish also contains some short fables with speaking animals (418-419: silkworm and spider; 419: bear and human; 450: frog; 474: a bird speaking bi-lisān al-hāal).

6o Ibn Abī 'Awn, Ajwiba, 126-127, in a section entitled Min amthāl al-Yūnāniyyìn.

61 Ḥuṣrī, Jam'al-jawāhir, 367: Nawādir yuhkāa 'an ghayr al-nās.

62 Ibn Ḥamdūn, Tadhkira, III, 141-42, VII, 221-22, 250-51, VIII, 239-40.

63 Marzūqī, Azmina, 269-270: Fìmā wuḍi'a 'alā alsinat al-bahāim.

64 Wholly Greek in origin are the animal fables fancifully ascribed to individual Greek philosophers in the anonymous seventh/thirteenth-century Fiqar al-hukamä, 234-236, 239-242, 244-245, 247-248, 249-251, 253-254, 257-259, 263-266, 293-294, 296. I thank Ignacio Sánchez for this reference.

65 Ābī, Nathr al-durr, viI, 275, cf. Perry's Index no. 149 and cf. no. 339 "The Lion's Share," several versions (for this index see Babrius and Phaedrus, Fables, 419-611). See also Brockelmann, Fabel und Tiermärchen, 99-10o. Found also in Jarīrī, Jalīs, II, 16o; Ibn Hamdūn, Tadhkira, viı, 222; Ibn al-Jawzī, Adhkiyā', 268; Damīrī, Hayāh, I, 176; etc. 
a fox; ${ }^{66}$ or "The Fox and the Thornbush." ${ }^{\prime 7}$ Some fables quoted by al-Ābī are non-Aesopic but known from other sources, such as the tale of the bird (qunbura) who is caught but escapes and teaches his catcher three lessons, found in other Arabic sources such as al-'Iqd al-farīd and Ibn Ḥamdūn's Tadhkira but also in Bilawhar wa-Büdhāsfi, ${ }^{68}$ or the well-known story of the two owls who expect a bride price of numerous ruins if a certain vizier or governor (variously identified) remains in office. ${ }^{69}$ Another tale looks Aesopian, faintly reminiscent of "Fox and Crow"70 yet very different and with an interesting punchline: ${ }^{71}$

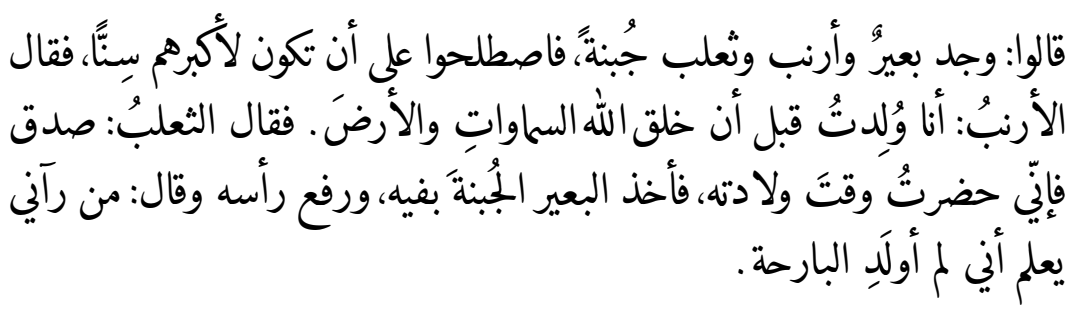

They say that a camel (bair), a hare (arnab), and a fox (thalab) found a piece of cheese. They agreed that it should go to the oldest of them. The hare said, "I was born before God created the heavens and the earth." The

66 Perry's Index, 15. Ābī, Nathr al-durr, viI, 275; Ibn Abī 'Awn, Ajwiba, 126; 'Askarī, Jamhara, II, 68; Maydānī, Majma` al-amthāl, II, 62; Tha'ālibī, al-Tamthīl wa-l-muhạậara, 358; Raghib al-Iṣbahānī, Muḥạḍarāt, II, 416. The four last-mentioned sources quote three anonymous lines of poetry: "You who blame Salmā, I find you are like a fox || Who wanted a bunch of grapes, but, seeing it was too high for him, || Said, 'Those are sour!' when he saw he could not reach them."

67 Perry's Index, 19; Ābī, Nathr al-durr, viI, 276; Ibn Abī 'Awn, Ajwiba, 126-127; Rosenthal, A Small Collection, no. viII; Marzolph, Arabia ridens, II, 73 (no. 285).

68 Ābī, Nathr al-durr, VII, 277-278; Ibn 'Abd Rabbih, Iqd, III, 68; Ibn Ḥamdūn, Tadhkira, viıI, 239-40; Ibn al-Jawzī, Adhkiyā', 309-310; Bilawhar wa-Büdhāsf, 66-68, "The Fowler and the Nightingale" (French tr., 108-109). It became known in Europe too, see Petrus Alphonsi, Disciplina clericalis, tr. Hermes, 189-19o, English tr., 141-142 and 186-87 note 116; and in Gesta Romanorum (compiled late thirteenth or early fourteenth century), see Gesta Romanorum: Entertaining Moral Stories, no. 167 ("Of hearing good counsel"), 347-348, notes pp. 457-46o. On this tale see also Marzolph, 101 Middle Eastern Tales, 38-44.

69 Ābī, Nathr al-durr, VII, 278-279 (with Abū Ayyūb al-Mūriyānī as the vizier of al-Manșūr); cf. Mas'ūdī, Murūj, I, 293 (set in the time of Bahrām b. Bahrām b. Hurmuz); Rāghib al-Iṣbahānī, Muhạạdarāt, I, 101; Ibn Badrūn, Sharh Qaṣīdat Ibn 'Abdūn, 29-30; Ṭurțūshī, Sirāj al-mulūk, 370; Damīrī, Hayāt al-hayawān, I, 16o; Ibshīhī, Mustațraf, I, 108; Qalqashandī, Șubhal-a'shä, II, 83; 1001 Nights, in the cycle of The Forty Viziers. On this tale see Marzolph \& Van Leeuwen, The Arabian Nights Encyclopedia, I, 280 and Marzolph, Arabia ridens, II, 103 (no, 414).

$70 \quad$ Perry's Index, no. 124.

71 Ābì, Nathr al-durr, VII, 275-276. 
fox said, "He has spoken the truth, [276] and I was present at his birth." Then the camel picked up the piece of cheese with his mouth, raised his head, and said, "Whoever sees me knows that I wasn't born yesterday."

Strikingly, it is not the fox who gains the prize, as no doubt he would have done in Aesop. One does not associate the camel with cunning or wit, or with eating cheese for that matter. The last sentence, "I wasn't born yesterday," is a remarkably old occurrence of this saying with the sense of "you cannot fool me." Another fable reminds one of the English saying "The owl thinks her own young fairest": ${ }^{72}$

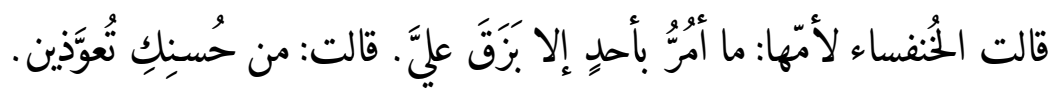

They say that the dung beetle (or scarab beetle, khunfus $\vec{a}$ ) said to her mother, "Whenever I meet anyone they spit on me." "That is," replied the mother, "to ward off the evil eye, because you are so beautiful."

Few animals are more repulsive, to humans, than the dung-beetle. Nevertheless, beauty is relative and in the eye of the beholder. Erasmus, in his Adages, describes the beauties of the dung-beetle at some length in an essay on the saying scarabaeus aquilam quaerit ("A dung-beetle hunting an eagle"); it could have been written by al-Jāḥiz: ${ }^{73}$

As far as physical beauty goes, if only we keep our judgment free of vulgar prejudice, there is no reason to despise the dung-beetle. For if the philosophers are right when they say that the shape they call a sphere is not only the most beautiful but in every way the best (...) why should

72 Ābī, Nathr al-durr, vII, 277; Ibn Qutayba, 'Uyūn al-akhbār, IV, 41; Ḥușrī, Jam' al-jawāhir,

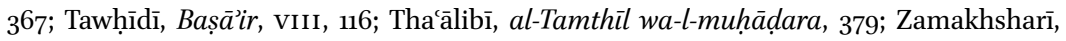
Rabī al-abrār, III, 525. Compare the anonymous verse "God made her appear beautiful to the eyes, just as | He made a child appear beautiful to its father," quoted in Ibn Qutayba, 'Uyūn, III, 95; Mubarrad, Kāmil, I, 305; Damīrī, Hayāt al-hayawān, I, 196, in the section about the ju'al (also "dung-beetle," "scarab" or "black beetle," said to be bigger than the khunfus $\left.\vec{a}^{\prime}\right)$. An anonymous reader mentioned the Egyptian Arabic proverb al-ird fi 'ên ummu ghazāl, "a monkey is a gazelle in its mother's eye." It goes back, in fact, to ancient Greek (Perry's Index, no. 364, "The Ape Mother and Zeus").

73 Erasmus, The Adages, 297. Al-Jāhiz, as it happens, is not very positive about the khunfus $\vec{a}$, but he mentions the ju'al, with the mosquito, butterfly, fly, locust etcetera, among the creatures that should not be despised (al-Hayawān, III, 303). 
the dung-beetle not seem beautiful which comes far closer to this shape than the eagle? (...) The colour of the dung-beetle, I think, no one will denigrate for it has the quality of jewels (...)

It will be clear by now, from this heterogeneous collection of quotations, that speaking animals fulfil many functions. They speak in the moralistic fables of the Aesopic kind; in a few aetiological, "just-so" stories; in proverbs or tales that purport to explain proverbs; in lexicographical sayings; in miracle tales involving prophets or pious people; in dreams, as when the famous musician Ibrāhīm al-Mawșilī (d. 188/804) dreams of a black and white cat who does not only speak but teaches him a beautiful song. ${ }^{74}$ They are usually anonymous, but the moral and artfully crafted fables by al-Ma'arrī are an exception. The anonymous Bedouin tales are sometimes denigrated as the takädhīb or $a k \bar{a} d h \bar{\imath} b$, "lies" or "fictitious stories" of the Bedouin Arabs. They come in different lengths. Explaining the saying ajra' min khāșì l-asad, "more daring than the man who castrated the lion," al-Maydānī, in his book on proverbs, tells the story in a mere thirty-five words: ${ }^{75}$

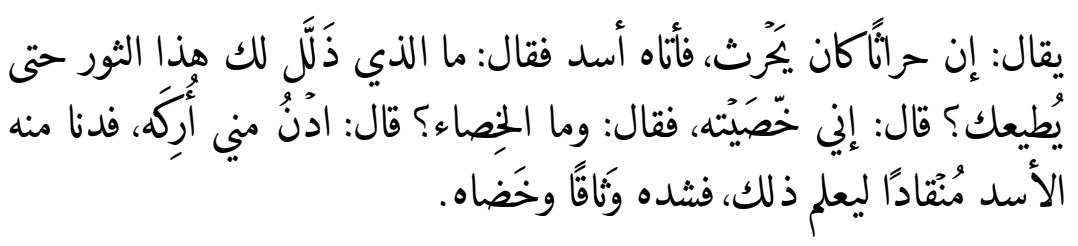

It is said that a farmer was ploughing when a lion came up to him and asked, "How did you manage to tame this ox so that it obeys you?" The farmer replied, "I have castrated it." "What is castration?" asked the lion. "Come closer and I'll show you," said the farmer. The lion came closer, compliantly, in order to find out. The farmer bound him tight and castrated him.

Al-Zamakhsharī (d. 538/1144) pares it down to even fewer words, calling it "one of the fictitious stories (takādhīb)" of the Bedouin Arabs. ${ }^{76}$ Abū 'Ubayd al-Bakrī

\footnotetext{
74 Abū l-Faraj al-Iṣfahān̄̄, Aghānī, v, 193-194.

75 Maydānī, Majmać, I, 240. Tha'ālibī, Thimāa al-qulūb, 383 mentions the expression khāṣ̄ l-asad but does not give the story.

${ }_{76}$ Zamakhsharī, Mustaqșā, I, 46.
} 
(d. 487/1094), however, offers what he calls a hadīth tawill, a relatively long and bizarre tale that can no longer be called a very short animal fable: ${ }^{77}$

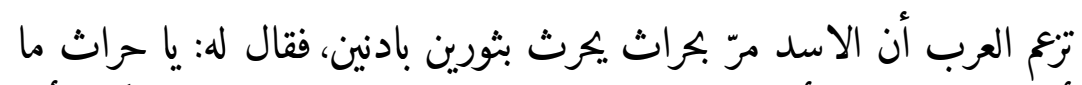

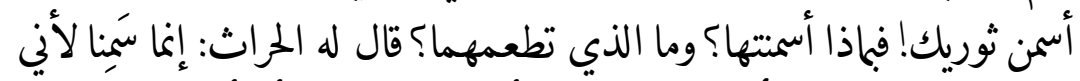

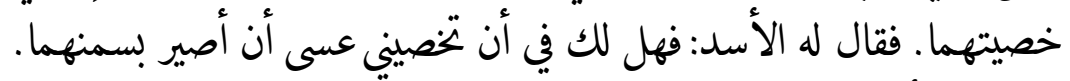



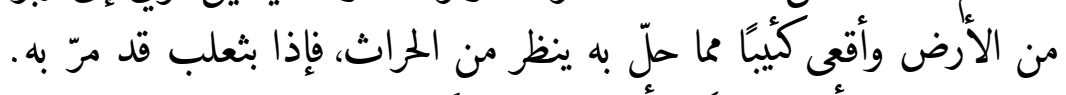

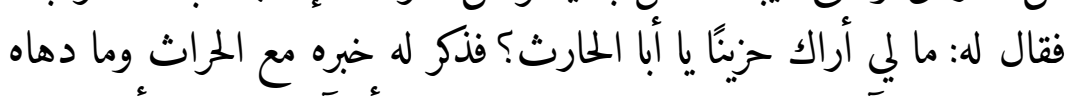

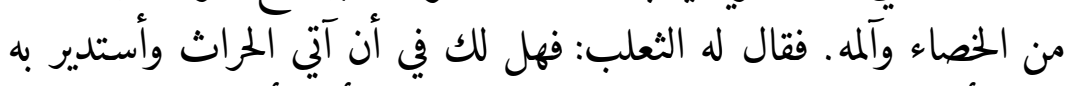

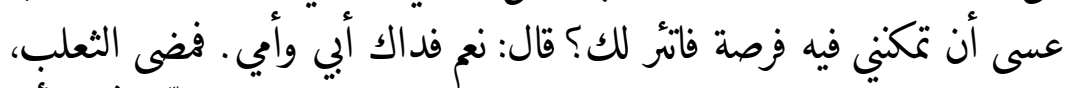



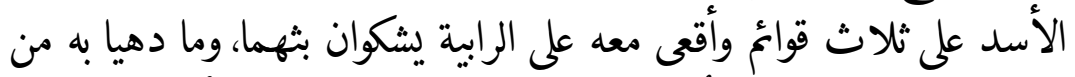

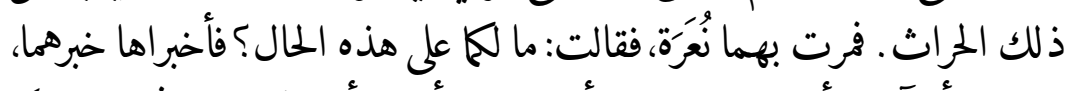

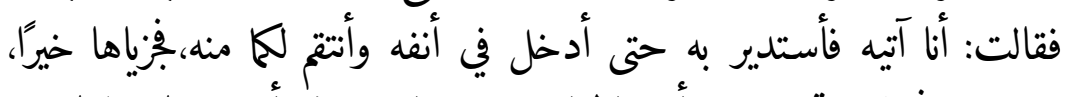

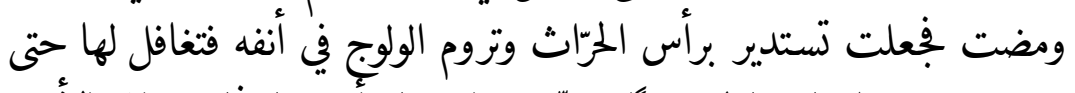

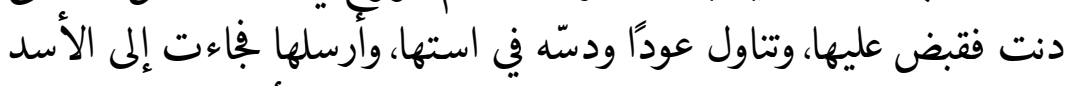
والثعلب وهي في شرٍ من حالهما، قد سدّ العود دبرها وأثقلها عن الطيران.

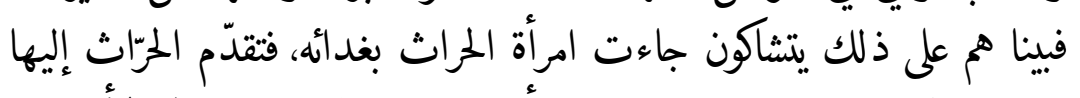

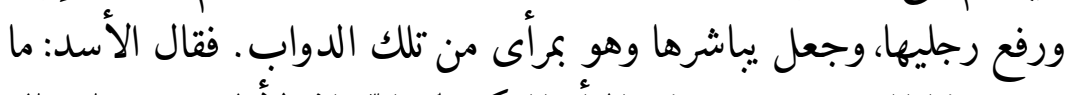

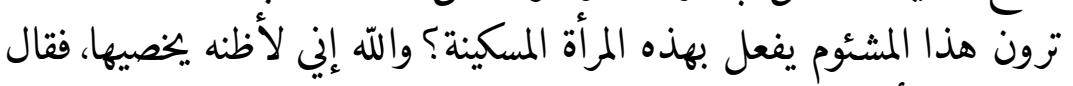

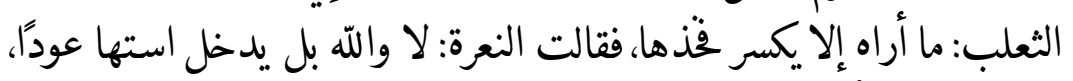
فكانت النعرة أصدقهن ظنًا.

The Arabs maintain that a lion once came past a farmer who was ploughing his field with two fat oxen. "Farmer," said the lion, "What fat oxen you have! How did you fatten them? What food did you give them?" The farmer replied, "They are fat because I have castrated them." The lion 
said, "Would you like to castrate me, so that I may grow as fat as they?" "Yes," the farmer replied. The lion submitted to the farmer, who castrated him. He left, still bleeding, and having ascended a hillock he squatted down, grieving about what had happened to him and keeping an eye on the farmer. A fox came past, who said, "Abu l-Hārith! Why is it that I see you sad?" The lion told him what the farmer had done to him and how the castration had hurt him. The fox said to him, "Would you like me to go to the farmer and make circles around him, so that I may have an opportunity to take revenge for you?" "Yes," answered the lion, "I would give my father and mother as your ransom!" The fox went to the farmer, moving around him while dodging him. The farmer took up a stone, threw it to the fox and broke its thigh. Limping on three legs the fox returned to the lion and squatted down with him on the hillock, lamenting their fate and what that farmer had done to them. A horsefly (nu'ara) came past. "What has happened to you two?" she asked. They told her their story. She said, "I shall go to him, fly around him and then creep into his nose, so that I can take revenge for you!" "God bless you!", they replied, and the fly set off and began to circle around the farmer's head, attempting to enter his nose. The farmer pretended to ignore her and when she got near he grabbed her. He took up a splinter and pushed it up her arse. Then he let her go. She returned to the lion and the fox in a state worse than theirs, with the splinter blocking her fundament and being too heavy to fly with. While they were lamenting, the farmer's wife came past with his lunch. The farmer went up to her, raised her legs and had intercourse with her in full sight of the animals. The lion said, "Do you see what that wretched man is doing with that poor woman? I swear to God, I think he is castrating her!" The fox replied, "No, he is in fact breaking her thigh!" And the horsefly said, "No, by God, he is putting a wooden splinter into her arse!" The horsefly was closest to the truth.

I suppose a moral may be extracted from the tale in its several forms, but it seems more likely that the story was invented to explain the hyperbolical expression. The longer, farcical version told by Abū 'Ubayd al-Bakrī, apart from being entertaining, could serve as an illustration of the unreliability of witnesses, all of whom will relate an observed incident to themselves and claim their subjective experience to be the truth. At the same time, it improves on the version of al-Maydānī and al-Zamakhsharī, because it is not clear why the lion would submit to being castrated in order to be tamed, whereas becoming fat, as in Abū 'Ubayd's version, would presumably be desirable. By dismissing the story as "one of their lies" instead of appreciating it as entertaining fiction, 
al-Zamakhsharī, not the least of scholars, demonstrates his obtuseness in dealing with the genre of the fable, as do al-Mubarrad and others when they speak of the "lies of the Bedouins" and even al-Ma'arri when he mentions the "lies of Jews and Christians."78 Likewise, when al-Qāḍi al-Jurjānī, quoted above by al-Tha'ālibī, speaks of ignorant nations and gullible Arabs who believe stories about speaking animals, one is tempted to think that he himself is gullible in believing in the gullibility of those who tell fables and listen to them.

\section{References}

\section{Primary Sources}

Al-Ābī, Abū Sa'd Manșūr b. al-Ḥusayn, Nathr al-durr, ed. by Muhammad 'Alī Qurana et al., 7 vols., Cairo: al-Hay’a al-Mișriyya al-Āmma, 1980-199o.

Abū Nu'aym al-Iṣbahānī, Hilyat al-awliyā’ wa-țabaqāt al-aşfyyā', 10 vols., Cairo: Mațba'at al-Sac̄àda \& Maktabat al-Khānjī, 1932-1938.

Abū l-Ṭayyib al-Lughawī, Marātib al-naḥwiyyìn, ed. by Muḥammad Abū l-Faḍl Ibrāhīm, Cairo: Nahḍat Mișr, [1974, date of preface].

Abū 'Ubayd al-Bakrī, Faṣl al-maqūl fìsharh al-amthāl, wa-huwa sharh li-kitāb al-Amthāl li-Abì 'Ubayd al-Qāsim b. Sallām, ed. by Iḥsān 'Abbās and 'Abd al-Majīd 'Ābidīn, Beirut: Dār al-Amāna, 1983 .

Abū Zayd al-Anșārī, al-Nawādir fì l-lugha, ed. by Muḥammad 'Abd al-Qādir Aḥmad, Beirut: Dār al-Shurūq, 1981.

Alf Layla wa-layla, Būlāq: al-Mațba'a al-'Āmira al-'Uthmāniyya, AH 1302.

The Arabian Nights: Tales of 1001 Nights, tr. by Malcolm C. Lyons, with Ursula Lyons, introduced and annotated by Robert Irwin, London: Penguin Classics, 2008.

Al-'Askarī, Abū Hilāl al-Ḥasan b. 'Abdallāh b. Sahl, al-Awā̄il, Beirut: Dār al-Kutub al-'Ilmiyya, 1987.

Al-'Askarī, Abū Hilāl al-Ḥasan b. 'Abdallāh b. Sahl, Jamharat al-amthāl, ed. by Aḥmad 'Abd al-Salām and Abū Hājar Muhammad Sa'̄ìd b. Basyūnī Zaghlūl, 2 vols., Beirut: Dār al-Kutub al-'Ilmiyya, 1988.

Al-Așma'ī, Abū Sa'īd 'Abd al-Malik b. Qurayb, al-Shā', ed. by Ṣabīḥ al-Tamīmī, Beirut: Dār Usāma, 1987.

Babrius and Phaedrus, Fables, tr. by Ben Edwin Perry, n. pl.: Harvard University Press, 1965 (Loeb Classical Library, 436).

78 On the problems of mediaeval $u d a b \bar{a}$ in dealing with fiction in general, see Bonebakker, Nihil obstat; Drory, Three Attempts; and several studies in Kennedy (ed.), On Fiction and Adab and Leder (ed.), Story-telling. 
Al-Baghdādī, 'Abd al-Qādir, Khizānat al-adab wa-lubāb lisān al-'Arab, ed. by 'Abd al-Salām Muḥammad Hārūn, 13 vols., Cairo: Dār al-Kātib al-'Arabī / al-Hay’a al-Mișriyya al-'Āmma, 1967-1986.

Bilawhar wa-Yūdāsaf/Būdhāsf, ed. by Daniel Gimaret, Beirut: Dār al-Mashriq, 1972; French tr. by Daniel Gimaret, Le Livre de Bilawhar et Būdāsf selon la version arabe ismaélienne, Genève - Paris: Librairie Droz, 1971.

Al-Damīrī, Kamāl al-Dīn, Hayāt al-hayawān al-kubrā, 2 vols., Cairo: al-Maktaba al-Tijāriyya al-Kubrā, repr. Beirut: Dār al-Fikr, n.d.

Erasmus, The Adages, selected by William Barker, Toronto: University of Toronto Press, 2001.

Fiqar al-ḥukamā', in Rasā̉il falsafiyya li-l-Kindī wa-l-Fārābì wa-Ibn Bājja wa-Ibn 'Adī, ed. by 'Abd al-Raḥmān Badawī, Beirut: Dār al-Andalus, 1983 .

Gesta Romanorum: Entertaining Moral Stories, tr. by Charles Swan, London: Routledge, 1905.

Ḥājjī Khalīfa, Kashf al-zunūn 'an asāmī l-kutub wa-l-funūn, ed. by Şerefettin Yaltkaya and Rifat Bilge, 2 vols., Istanbul: Maarıf Matbaası, 1941-1943.

Al-Ḥuṣrī, Abū Isḥāq Ibrāhīm b. 'Alī al-Qayrawānī,Jam'al-jawāhirfíl-mulaḥwa-l-nawādir, ed. by 'Alī Muhammad al-Bajāwī, repr. Beirut: Dār al-Jīl, 1987 .

Ibn 'Abd Rabbih, Abū 'Umar Aḥmad b. Muhammad, al-Iqd al-farīd, ed. by Aḥmad Amīn, Aḥmad al-Zayn, Ibrāhīm al-Abyārī, 7 vols., Cairo, 1948-1953, repr. Beirut: Dār al-Kitāb al-'Arabī, 1983 .

Ibn Abī 'Awn, al-Ajwiba al-muskita / Das Buch der schlagfertigen Antworten von Ibn Abī 'Awn. Ein Werk der klassisch-arabischen Adab-Literatur, Einleiting, Edition und Quellenanalyse, by May A. Yousef (Mayy Aḥmad Yūsuf), Berlin: Klaus Schwarz, 1988 (Islamkundliche Untersuchungen, 125).

Ibn Badrūn, Sharh Qașīdat Ibn 'Abdūn / Ibn Badroun, Commentaire sur le poème d'IbnAbdoun, ed. by R.P.A. Dozy, Leiden: Luchtmans, 1848.

Ibn Durayd, Abū Bakr Muhammad b. al-Ḥasan,Jamharat al-lugha, ed. by Ramzī Munīr Ba labakkī, 3 vols., Beirut: Dār al-'Ilm li-l-Malāyīn, 1987 .

Ibn Ḥamdūn, Muḥammad b. al-Ḥasan b. Muḥammad b. 'Alī, al-Tadhkira al-Hamdūnìyya, ed. Iḥsān 'Abbās and Bakr 'Abbās, 10 vols., Beirut: Dār Ṣādir, 1996.

Ibn Harma, Ibrāhīm - al-Qurashī, Shi'r, ed. by Muḥammad Naffāe and Ḥusayn 'Ațwān, Damascus: Majma' al-Lugha al-'Arabiyya, 1969.

Ibn Iyās, Muḥammad b. Aḥmad (attrib.), Badā'ic al-zuhūrfíwaqā̉ic al-duhūr, Cairo: 'Īsā al-Bābī al-Halabī, n.d. [not the history by Ibn Iyās but a different work, probably by another author].

Ibn al-Jawzī, Jamāl al-Dīn Abū l-Faraj 'Abd al-Raḥmān b. 'Alī, Akhbār al-adhkiyā', ed. by Bassām 'Abd al-Wahhāb al-Jābī, Beirut: Dār Ibn Ḥazm, 2003.

Ibn al-Jawzī, Abū l-Faraj Jamāl al-Dīn 'Abd al-Raḥmān b. 'Alī, al-Mud'hish, ed. Marwān Qabbānī, Beirut: Dār al-Kutub al-'Ilmiyya, 2005. 
Ibn Manẓūr, Jamāl al-Dīn Muhammad b. Mukarram al-Anșārī, Lisān al-Arab, 20 vols., Cairo: al-Dār al-Mișriyya li-l-Ta’līf wa-l-Tarjama, n.d. (repr. of ed. Būlāq, АН 1300-1308).

Ibn al-Muqaffac, Kalīla wa-Dimna, ed. by Luwīs Cheikho, Beirut: Maṭba'at al-Ābā’ al-Yasū'iyyīn, 1922.

Ibn al-Muqaffa', Kalīla wa-Dimna, Beirut: Dār Șādir, 1984.

Ibn al-Nadīm, Abū l-Faraj Muḥammad b. Abī Ya'qūb Isḥāq - al-Warrāq al-Baghdādī, al-Fihrist, ed. by Ayman Fu'ād Sayyid, 4 vols., Cairo: Al-Furqān Islamic Heritage Foundation, 2014.

Ibn Qutayba al-Dīnawarī, Kitāb al-Ma'ānī l-kabīr fì abyāt al-ma'ānī, 2 vols., Hyderabad: Dāirat al-Ma'ārif al-'Uthmāniyya, 1949.

Ibn Qutayba, Abū Muhammad 'Abdallāh b. Muslim - al-Dīnawarī, al-Shi'rwa-l-shu'arā', ed. by Aḥmad Muḥammad Shākir, 2 vols., Cairo: Dār al-Ma'ārif, 1966-1967.

Ibn Qutayba, Abū Muḥammad 'Abdallāh b. Muslim, Ta’wīl mukhtalif al-Hadīth, ed. by Muḥammad Muḥȳi l-Dīn al-Aṣfar, Beirut: al-Maktab al-Islāmī, 1999.

Ibn Qutayba, 'Uyūn al-akhbār, 4 vols., Cairo: Dār al-Kutub, 1925-193o, repr. al-Hay’a al-'Āmma li-l-Kitāb, 1972.

Al-Ibshīhī, Shihāb al-Dīn Muḥammad b. Aḥmad, al-Mustaṭraf fì kull fann mustazraf, 2 vols., Cairo: Muṣțafā l-Bābī al-Ḥalabī, $195^{2}$.

Al-Ișfahānī, Abū l-Faraj, al-Aghānī, 24 vols., Cairo: Dār al-Kutub / al-Hay’a al-Mișriyya al-'Āmma, 1927-1974.

Al-Jāḥiz, al-Bayān wa-l-tabyīn, ed. by 'Abd al-Salām Muḥammad Hārūn, 4 vols., ț. 3 Cairo: Maktabat al-Khānjī, 1968.

Al-Jāḥiz, al-Hayawān, ed. by 'Abd al-Salām Muḥammad Hārūn, 8 vols., ț. 2 Cairo: Mușțafā al-Bābī al-Ḥalabī, 1965-1969.

Al-Jarīn̄i, Abū l-Faraj al-Mu'āfā b. Zakariyyā al-Nahrawānī, al-Jalīs al-șāliḥ al-kāfì wa-l-anīs al-nāṣịh al-shāfì, ed. by Muḥammad Mursī al-Khawlī and Iḥsān 'Abbās, 4 vols., Beirut: 'Ālam al-Kutub, 1993.

Al-Jawālīqī, Mawhūb, Sharḥ Adab al-kātib, ed. by Ṭayba Ḥamad Būdī, Kuwait: Jāmi'at al-Kuwayt, 1995 .

Al-Kalāìi, Abū l-Qāsim Muḥammad b. 'Abd al-Ghafūr, Iḥām șan'at al-kalām, ed. by Muḥammad Rị̣wān al-Dāya, Beirut: Dār al-Thaqāfa, 1966.

Al-Khalīl b. Aḥmad, al-'Ayn, ed. by Mahdī al-Makhzūmī and Ibrāhīm al-Sāmarrā̄̄î, 8 vols., Baghdad: Dār al-Rashīd, 1980-1985.

Al-Ma'arrī, Abū l-'Alā', Risālat al-Ṣāhil wa-l-shāhịj, ed. by 'Ā’isha 'Abd al-Raḥmān, ț. 2, Cairo: Dār al-Ma'ārif, 1984.

Al-Maqdisī, al-Bad' wa-l-ta'rīkh, ed. by Clément Huart, 6 vols., Paris: Ernest Leroux, 1899-1919, repr. Baghdad: Maktabat al-Muthannā, n.d.

Al-Marzūqī, Abū 'Alī Aḥmad b. Muhammad, al-Azmina wa-l-amkina, ed. by Khalīl al-Manșūr, Beirut: Dār al-Kutub al-'Ilmiyya, 1996. 
Al-Mas'ūdī, Murūj al-dhahab, ed. by Barbier de Meynard \& Pavet de Courteille, 7 vols., revue et corrigée par Charles Pellat, Beirut: al-Jāmi'a al-Lubnāniyya, 1966-1979.

Al-Maydānī, Abū l-Fạ̣l Aḥmad b. Muḥammad, Majma' al-amthāl, ed. by Na'īm Ḥusayn Zarzūr, 2 vols., Beirut: Dār al-Kutub al-'Ilmiyya, 1988.

Al-Mubarrad, Abū l-'Abbās Muhammad b. Yazīd, al-Kāmil fíl-lugha wa-l-adab, ed. by 'Abd al-Ḥamīd Hindāwī, 4 vols., Beirut: Dār al-Kutub al-'Ilmiyya, 1999.

Al-Mufaḍḍal b. Salama b. 'Āṣim al-Ḍabbī, al-Fākhir fì l-amthāl, ed. by Muhammad 'Uthmān, Beirut: Dār al-Kutub al-'Ilmiyya, 2011.

Al-Murtạ̣ā, 'Alī b. al-Ḥusayn al-Sharīf, al-Amālì (Ghurar al-fawā̉id wa-durar al-qalāidd), ed. by Muhammad Abū l-Fạ̣l Ibrāhīm, 2 vols., in 1, Cairo: 'Īsā l-Bābī al-Ḥalabī, 1373/1954.

Al-Nuwayrī, Shihāb al-Dīn Aḥmad b. 'Abd al-Wahhāb, Nihāyat al-arabfífunūn al-adab, 33 vols., Cairo: Dār al-Kutub, 1923-2007.

Petrus Alphonsi, Die Kunst, vernünftig zu Leben (Disciplina clericalis), tr. by Eberhard Hermes, Zürich: Artemis, 1970.

Petrus Alphonsi, The Disciplina Clericalis, tr. by Eberhard Hermes, tr. into English by P.R. Quarrie. London: Routledge \& Kegan Paul, 1977.

Al-Qālī, Abū 'Alī Ismācīl b. al-Qāsim, al-Amālī, 2 vols., Cairo: Dār al-Kutub al-Mișriyya, 1926, repr. Beirut: Dār al-Āfāq al-Jadīda, n.d.

Al-Qalqashandī, Abū l-'Abbās Aḥmad, Șubḥ al-a shhā fí șinā'at al-inshā, 14 vols., Cairo: Dār al-Kutub, 1913-1922.

Al-Rāghib al-Iṣfahānī, Muhạậarāt al-udabā' wa-muhāwarāt al-shu'arā', 2 vols., Būlāq: Mațba'at Ibrāhīm al-Muwaylihīi, AH 1287.

Ru'ba b. al-'Ajjāj, Dīwān / Der Dīwān des Reḡezdichters Rūba ben Elảḡḡāḡ, ed. by W[ilhelm] Ahlwardt, Berlin, 1903 (Sammlungen alter arabischer Dichter), repr. Beirut: Dār al-Āfāq al-Jadīda, 198o.

Al-Ṣafadī, Șalāḥ al-Dīn Khalīl b. Aybak, al-Wāfíbi-l-wafayāt / Das biographische Lexikon des Șalāhaddīn Halīl ibn Aibak aṣ-Ṣafadī, 30 vols., Beirut - Wiesbaden - Berlin: Franz Steiner - Klaus Schwarz, 1931-2005.

Al-Sarrāj, Abū Muḥammad Ja‘far b. Aḥmad - al-Qāri’, Maṣāri` al-'ushshāq, 2 vols., Beirut: Dār Ṣādir, n.d.

Sībawayh, Abū Bishr 'Amr, Kitāb Sībawayh, 2 vols., Cairo: Dār al-Ṭibāac, AH 1317-1318, repr. Baghdad: Maktabat al-Muthannā, n.d.

Al-Suyūțī, 'Abd al-Raḥmān Jalāl al-Dīn, al-Muzhir fì 'ulūm al-lugha wa-anwā ihā, ed. by Muḥammad Aḥmad Jād al-Mawlā, 'Alī Muḥammad al-Bijāwī, and Muḥammad Abū l-Fạ̣l Ibrāhīm, 2 vols., Cairo: Dār Iḥyā’ al-Kutub al-'Arabiyya, n.d.

Ta'rîf al-qudamā’ bi-Abì l-'Alä', Cairo: al-Dār al-Qawmiyya li-l-Ṭibā'a wa-l-Nashr, 1965 . Al-Tawhīì̄î, Abū Ḥayyān 'Alī b. Muḥammad b. al-Abbās, al-Bașā̉ir wa-l-dhakhā’ir, ed. by Wadād al-Qāḍī, 9 vols., Beirut: Dār Șādir, 1988. 
Al-Tha'ālibī, Abū Manșūr 'Abd al-Malik b. Muhammad b. Ismā̄īl, al-Tamthīl wa-lmuḥậ̣ara, ed. by Muḥammad 'Abd al-Fattāḥ al-Ḥulw, Beirut: al-Dār al-'Arabiyya li-l-Kitāb, 1983 .

Al-Tha'ālibī, Abū Manșūr 'Abd al-Malik b. Muhammad b. Ismāc̄il al-Nīsābūrī, Thimār al-qulūb fìl-muḍāf wa-l-mansūb, ed. by Muḥammad Abū l-Faḍl Ibrāhīm, Cairo: Dār al-Macārif, 1985 .

Tha'lab, Abū l-Abbās Aḥmad b. Yaḥyā, Majālis Tha lab, ed. by 'Abd al-Salām Muḥammad Hārūn, 2 vols., Cairo: Dār al-Maārif, (vol. 1: ț. 5) 1987, (vol. 2: ț. 4) 198o.

Al-Ṭurțūshī, Muḥammad b. al-Walīd, Sirāj al-mulūk, ed. by Ja'far al-Bayātī, London: Riyāọ al-Rayyis (Riad El-Rayyes), 1990.

Umayya b. Abī l-Ṣalt, Dīwān, ed. by Sajīi Jamīl al-Jubaylī, Beirut: Dār Șādir, 1998.

Al-Zabīdī, Murtaḍā, Tāj al-'arūs, ed. by 'Abd al-Sattār Farrāj, 40 vols., Kuweit: Maṭba'at Hukūmat al-Kuwayt, 1965-2001.

Yāqūt, Mu'jam al-udabā', ed. by Aḥmad Farīd Rifā̄î̀, 20 vols., Cairo, 1936-1938, repr. Beirut: Iḥyā' al-Turāth al-'Arabī, n.d.

Al-Zamakhsharī, Abū l-Qāsim Jār Allāh Maḥmūd b. 'Umar, al-Mustaqșā fì amthāl al-'Arab, 2 vols., Hyderabad: Dāiirat al-Ma'ārif al-'Uthmāniyya, 1962.

Al-Zamakhsharī, Maḥmūd b. 'Umar, Rabī al-abrār wa-nușūṣ al-akhbār, ed. by Salīm al-Nu'aymī, 4 vols., Baghdad: Mațba'at al-'̄̄nī, 1976-1982.

\section{Secondary Sources}

Bonebakker, S.A., Nihil obstat in story-telling?, Mededelingen der Koninklijke Nederlandse Akademie van Wetenschappen, 55/8 (1992), 289-307 [a version of this also published in: Richard G. Hovannisian \& Georges Sabagh (eds.), The Thousand and One Nights in Arabic Literature and Society, Cambridge: Cambridge University Press, 1997, 56-77].

Brockelmann, Carl, Fabel und Tiermärchen in der älteren arabischen Literatur, in: Islamica, 2 (1926), 96-106.

Drory, Rina, Three Attempts to Legitimize Fiction in Classical Arabic Literature, in: Jerusalem Studies in Arabic and Islam, 18 (1994), 146-164 [also in: Rina Drory, Models and Contacts: Arabic Literature and its Impact on Medieval Jewish Culture, Leiden: Brill, 2000, 37-47].

Irwin, Robert, The Arabic Beast Fable, in: Journal of the Warburg and Courtauld Institutes, 55 (1992), 36-50.

Karimi, Gholam-Ali, Le conte animalier dans la littérature arabe avant la traduction de Kalila wa Dimna, in: Bulletin d'études orientales, 28 (1975), 51-56.

Kennedy, Philip F. (ed.), On Fiction and Adab in Mediaeval Arabic Literature, Wiesbaden: Harrassowitz, 2005 [Studies in Arabic Language and Literature, 6].

Kraeling, Carl H., The Mandaic God Ptahil, in:JAOS, 53 (1933), 152-165. 
Lane, Edward William, An Arabic-English Lexicon, 8 parts, London: Williams and Norgate, $1863^{-1893 .}$

Leder, Stefan (ed.), Story-telling in the Framework of Non-fictional Arabic Literature, Wiesbaden: Harrassowitz, 1998.

Marzolph, Ulrich, 101 Middle Eastern Tales and Their Impact on Western Oral Tradition, Detroit: Wayne State University Press, 2020.

Marzolph, Ulrich, Arabia Ridens. Die humoristische Kurzprosa der frühen adab-Literatur im internationalen Traditionsgeflecht, Band 1: Darstellung, Band 2: Material, 2 vols., Frankfurt am Main: Vittorio Klostermann, 1992 [Frankfurter wissenschaftliche Beiträge, Kulturwissenschaftliche Reihe, 21/2].

Marzolph, Ulrich, and Richard van Leeuwen, The Arabian Nights Encyclopedia, 2 vols., Santa Barbara, California: ABC Clio, 2004.

Miller, Jeannie, Man is Not the Only Speaking Animal: Thresholds and Idiom in al-Jāhiz, in: Joseph E. Lowry and Shawkat M. Toorawa (eds.), Arabic Humanities, Islamic Thought: Essays in Honor of Everett K. Rowson, Leiden: Brill, 2017 [Islamic History and Civilization, 141], 94-121.

Perry, Index see Babrius and Phaedrus, Fables, 419-611 [The Perry Index is also readily found online].

Rosenthal, Franz, A Small Collection of Aesopic Fables in Arabic Translation, in: Studia semitica necnon iranica Rudolpho Machuch ... dedicata, Wiesbaden: Harrassowitz, $1989,244-256$.

Salhi, Zahia Smail, and Hussain Mohammed Alqarni, New Images in Old Frames: Ibn Harma (d. ca. 176/792) between Classical Poetry and Abbasid Modernity, in:Journal of Abbasid Studies, 3 (2016), 56-89.

Sezgin, Fuat, Geschichte des arabischen Schrifttums. Band II: Poesie bis ca. 430 H., Leiden: Brill, 1975 .

Van Bladel, Kevin T., From Sasanian Mandaeans to Șābians of the Marshes, Leiden: Brill, 2017 [Leiden Studies in Islam and Society, 6].

Wagner, Ewald, Sprechende Tiere in der arabischen Prosa, in: Asiatische Studien, 48 (1994), 937-957. 